\title{
An overview of Defoliants Use in Cotton
}

\author{
S. Sravanthi*, M. Sree Rekha, B. Venkateswarlu, Ch. Sujani Rao and K. Jayalalitha
}

\author{
Agricultural College, Bapatla, Andhra Pradesh, India
}

*Corresponding author

\begin{abstract}
A B S T R A C T
\section{Keywords}

Cotton, defoliants and time of application

Article Info

Accepted:

08 June 2020

Available Online:

10 July 2020

Cotton production is labour intensive in almost all the developing countries where it is picked by hand. In recent times, due to acute labour shortage, mechanized harvesting is gaining momentum. Mechanized harvesting requires the application of defoliants, which reduces the cost of labour used for picking cotton and maximum cotton can be picked in a single pick. Farmers can go for next crop due to earliness in cotton and get benefit of two crops instead of one single long duration crop. Researchers have conducted various studies on defoliation in cotton using different chemicals and different defoliation methods. In this concern, defoliants and their time of application influence on growth, yield and defoliation percentage of cotton is provided in this overview.
\end{abstract}

\section{Introduction}

Cotton, the King of Fibres, is an important commercial crop which occupies a prime position in agro - industrial economy in India. India remains the leading country in terms of area under cotton cultivation and raw cotton production in the world.

Normally cotton is picked by hand, however, due to acute labour shortage, mechanized harvesting is gaining momentum. Mechanized harvesting of cotton requires the application of harvest- facilitating defoliants, chemicals to shed the leaves before harvesting at an appropriate time and to ensure clean and smooth picking of the seed cotton.Chemical defoliants therefore, form an integral part of package for achieving clean pickings, early termination and quality cotton in developing countries.

These chemicals necessary to increase harvest efficiency, reduce lodging, reduce trash, lint staining and to synchronize the opening of bolls thus allowing the farmer to obtain maximum yield with harvesting once and to facilitate mechanical harvesting. Proper time of defoliation involves balancing the value of potential increases in yield with the value of changes in fiber quality; hence its exploration is of prime importance for cotton growers for 
fetching maximum returns from their produce (Showler, 2009). Thus, time of application of harvest aid chemicals is very crucial which influence the yield of cotton. Defoliants application leads to earliness in cotton with synchronous maturity, vacating the field 1015 days earlier than the normal cotton. It paves way for introduction of short duration pulses like greengram in sequence.

\section{Influence of defoliantsin Cotton}

\section{Growth parameters}

Mrunalini et al., (2019) reported a reduction in plant height of non - Bt cotton variety, Suraj at 15 days after defoliant spray with Dropp Ultra 540 SC @ $200 \mathrm{ml} \mathrm{ha}^{-1}$ (applied at $60 \%$ boll opening) when compared to urea @ $15 \%$ in clay soils at Bapatla in Andhra Pradesh.

Results of an experiment on effect of mepiquat chloride applied to cotton at early bloom and physiological cut out conducted at Carolina by Collins et al., (2017) revealed that application of mepiquat chloride @ 0.1 $\mathrm{kg} \mathrm{ha} \mathrm{p}^{-1}$ at early bloom stage reduced plant height $(101.7 \mathrm{~cm})$ over control $(126.9 \mathrm{~cm})$ whereas, no significant differences were observed when applied at physiological cut out.Application of mepiquat chloride @ 1750 $\mathrm{ml} \mathrm{ha}{ }^{-1}$ recorded statistically least plant height over control as reported by Singh et al., 2017.Similar results were obtained in Kataria and Khanpara (2012).

A field experiment carried out by Meena et al., (2016) at Central Institute for Cotton Research, Sirsa, reported that there was significant reduction in plant height in two cotton genotypes i.e., variety $\mathrm{F} 1861$ and BthybridMRC7017,with even the lower concentrations of Thiadiuron@ $200 \mathrm{ml} \mathrm{ha}^{-1}$ $(120.3 \mathrm{~cm})$ and Etherel @ 2000 ppm $(121 \mathrm{~cm})$ as compared to control $(126.1 \mathrm{~cm})$.

\section{Yield attributes and seed cotton yield}

Singh et al., (2017) reported that the highest seed cotton yield $\left(2976 \mathrm{~kg} \mathrm{ha}^{-1}\right.$ ) was recorded with application of mepiquat chloride @ 1500 $\mathrm{ml} \mathrm{ha}{ }^{-1}$ due to improved boll weight $(3.92 \mathrm{~g}$ ) and bolls plant ${ }^{-1}$ (53.2) over the other treatments at Punjab Agricultural University, Faridkot.

A study conducted on medium black soils at UAS, Dharwad with compact cotton genotypes stated that genotype, RAH 274 with application of chemical defoliant Etherel @ 2000 ppm recorded higher yield attributes like sympodial branches per plant, number of bolls per plant, per cent boll open and yield per plant which resulted in higher seed cotton yield (2241 kg ha $\left.{ }^{-1}\right)$ over other combinations (Tuppad et al., 2017).

Meena et al., (2016) from Sirsa, reported that application of Thiadizuron 36\% SC + Diuron $18 \%$ SC @ $225 \mathrm{ml} \mathrm{ha}^{-1}$ gave significantly higher yield (23.79 $\left.\mathrm{q} \mathrm{ha}^{-1}\right)$, however it was found at par with $220 @ \mathrm{ml} \mathrm{ha}^{-1}\left(23.48 \mathrm{q} \mathrm{ha}^{-1}\right)$ and superior over Ethrel @ 2000 ppm (20.78 $\mathrm{q} \mathrm{ha}{ }^{-1}$ ) and control (19.73 $\left.\mathrm{q} \mathrm{ha}^{-1}\right)$.

Results of an experiment conducted by Fatullateshaev and Khaitov (2015) on effect of defoliants and fertilizers on yield and quality of American cotton (Bukhara) at Central Experimental Station of Uzabekistan, revealed that the higher cotton yield (42.5 q $\mathrm{ha}^{-1}$ ) was observed with application of defoliant Avguron extra $0.25 \mathrm{l} \mathrm{ha}^{-1}$ when associated with mineral fertiliser $\mathrm{N}_{250} \mathrm{D}_{175} \mathrm{E}_{125}$ $\mathrm{kg} \mathrm{ha}^{-1}$ than control (40.4 $\left.\mathrm{q} \mathrm{ha}^{-1}\right)$.

An experiment conducted by Kulvir and Pankaj (2015) on American cotton cultivars in sandy loam soils atPunjab Agricultural University, Faridkot revealed that Dropp ultra @ $200 \mathrm{ml} \mathrm{ha}^{-1}$ recorded significantly the highest seed cotton yield (3111.6 kg ha ${ }^{-1}$ ) 
followed by Ethrel @ 2000 ppm $(2948.3 \mathrm{~kg}$ $\left.\mathrm{ha}^{-1}\right)$ and control $\left(2878.9 \mathrm{~kg} \mathrm{ha}^{-1}\right)$.

\section{Percent defoliation in cotton}

Per cent defoliation was significantly higher with Dropp ultra@250 ml ha ${ }^{-1}$ (92.3\%) and it was on a par with Dropp ultra @ $200 \mathrm{ml} \mathrm{ha}$ ${ }^{1}$ (90 \%) and ethrel @ 3000 ppm (89\%) 7 days after application as reported by Raghavendra and Rama Reddy (2020) from Nandyal, Andhra Pradesh.

Wang Fang Yong et al., (2019) from China, reported that defoliation percentage 21 days after thidiazuron $180 \mathrm{ml} \mathrm{ha}^{-1}+$ ethrel $1200 \mathrm{ml}$ ha $^{-1}$ spray on XLZ 45 and XLZ 62 cotton cultivars was 92.7 and $90.5 \%$ under wide row high density planting and 89.3 and $91.1 \%$ under wide row low density planting, respectively.

Mrunalini and Sree Rekha (2018) from their study at Bapatla on clay soil, found that there was significant increase in per cent defoliation with Dropp ultra @ $200 \mathrm{ml} \mathrm{ha}^{-1}$ (99.7) at 15 days after defoliant spray followed by Dropp ultra @ $150 \mathrm{ml} \mathrm{ha}^{-1}(93.1)$ and the lowest percent defoliation was observed in urea @ $15 \%$.

Wang et al., (2018) from a two-year study conducted at China asserted that defoliation and boll opening percentages were significantly enhanced by 45 to $57 \%$ and by 35 to $41 \%$ after the application of harvest aids thidiazuron $900 \mathrm{~g}$ a.i $\mathrm{ha}^{-1}$ +ethephon $3000 \mathrm{~g}$ a.i ha ${ }^{-1}$ over other doses tested.

In a field experiment conducted at Sirsa by Meena et al., (2016) it was reported that $15^{\text {th }}$ day after defoliant spray, leaves shedding was significantly higher in both concentrations of Thiadiuron + Diuron@ 225 and $200 \mathrm{ml} \mathrm{ha}^{-1}$ (51.3 and 51.5\%) and ethrel @ 2000 ppm (45.6\%) compared to control (26.1\%).

\section{Effect of time of application of defoliants in cotton}

\section{Growth parameters}

Veeraputhiran and Gunasekaran (2020) from Srivilliputtur, Tamilnadu reported that significantly shorter plants were observed with application of mepiquat chloride thrice at square formation, flowering and boll development $(77.4 \mathrm{~cm})$ when compared to once at flowering $(89.8 \mathrm{~cm})$ or square formation $(86.9 \mathrm{~cm})$ or boll development $(93.1 \mathrm{~cm})$ and control $(99.4 \mathrm{~cm})$ under high density planting system of cotton.

Pooled results of a two year study from Punjab Agricultural University, Faridkot by Kulvir et al., (2015) revealed that application of defoliants at 140 DAS recorded significantly less plant height $(162.1 \mathrm{~cm})$ when compared to application of defoliants at 150 DAS $(165.6 \mathrm{~cm})$.

Karademir et al., (2007) reported that there were significant differences for plant height in second year of their study with application of defoliant, Thidiazuron + Diuron @ 600 ml ha

${ }^{1}$ with cotton variety Maras 92 . Shorter plant height was observed with defoliant spray at $60 \%$ boll opening $(93 \mathrm{~cm})$, which was on a par with $50 \%$ boll opening $(93.94 \mathrm{~cm})$ than $70 \%$ boll opening $(96.78 \mathrm{~cm})$ and control $(97.90 \mathrm{~cm})$.

\section{Yield parameters and seed cotton yield}

Results of an experiment conducted by Gormus et al., (2017) at Turkey, revealed that yields of the early harvest at late defoliation timing ( $90 \%$ boll opening) and late harvest at mid defoliation timing (70\% boll opening) gave significantly higher yields than all other treatments from two years of field studies. In a study conducted for two years at Punjab Agricultural University, Faridkot in American 
cotton, defoliants applied at 150 days after sowing (DAS) resulted in significantly higher yield (3017.7 $\mathrm{kg} \mathrm{ha}^{-1}$ ) as compared to early application at 140 DAS (2789.0 kg ha-1) owing to significantly improved boll retention and better boll weight (Kulvir and Pankaj, 2015).

Buttar and Singh (2013) from Punjab Agriculture University, Bathinda, reported that higher seed cotton yields at all the levels of Etherel were obtained when it was applied at 145 DAS as compared to 130 DAS during their two years of study.

The results had shown that application of Etherel @ 2500 ppm 145 DAS in Btcotton hybrid RCH 134 gave higher seed cotton yield coupled with timely vacation of the field.

Awan et al., (2012) reported that seed cotton yield was greater where defoliant was applied at $60 \%$ open bolls and sulphur was applied @ $24 \mathrm{~kg} \mathrm{ha}^{-1}$ when compared to $50 \%$ open bolls in cotton cultivar CIM-473. Harvesting was done 25 days earlier than control and lowest seed cotton yield was recorded in control at Pakistan.

Rajni et al., (2011) studied about defoliants in Bt cotton and found that application of ethrel at $60 \%$ boll opening produced numerically higher total seed cotton yield $\left(2.27 \mathrm{t} \mathrm{ha}^{-1}\right)$ than $40 \%$ boll opening $\left(2.11 \mathrm{t} \mathrm{ha}^{-1}\right)$, but was statistically at par with each other.

\section{Percent defoliation in cotton}

A two-year study conducted on black cotton soil at Nandyal, Andhra Pradesh with American cotton under semi-arid conditions revealed that significantly higher defoliation percentage was observed with defoliant spray at 140 DAS (92.2\%) compared to defoliant application at 120 DAS (87.2\%)
(Raghavendra and Rama Reddy, 2020). Gormus et al., (2017) reported that application of defoliant (mixtures of Finish (ethephon+cyclanilide) @ $1.75 \mathrm{~L} \mathrm{ha}^{-1}$ with Dropp Ultra (thidiazuron+diuron) @ $0.60 \mathrm{~L}$ $\mathrm{ha}^{-1}$ ) at $80 \%$ boll opening resulted in significantly lower number of green leaves (23.4) remaining on the plant at 28 days after defoliation over $40 \%$ boll open (37.8), $60 \%$ boll open (29) and control (57.5) in cotton varieties.

Ratna Kumari et al., (2013) from their experiment on seed yield of Bunny BG I cotton at Lam, Guntur, Andhra Pradesh stated that number of intact leaves on the plant were significantly reduced due to defoliant spray at 145 DAS compared to 130 DAS.

Osman et al., (2010) conducted an experiment at Turkey on clay soils with cotton variety cv. Stoneville-453, reported that number of leaves after application of dropp ultra at 60, 75 and 90 days after flowering were 3,7 and 25 , respectively whereas with Glyphosate application at 60,75 and 90 days after flowering were 60,55 and 46.

\section{Economics of cotton influenced by} defoliants and time of application

Mrunalini et al., (2019) from Bapatla, Andhra Pradesh reported that net returns (Rs. 61,223 $\mathrm{ha}^{-1}$ ) and $\mathrm{B}: \mathrm{C}$ ratio (2.18) were markedly higher with Dropp Ultra 540 SC @ 200 ml ha

1 when it was applied at 60 per cent boll opening percentage in non- Bt cotton variety 'Suraj' due to less cost of cultivation and higher yield.

Results from an experiment conducted by Singh et al., (2017) in north western India revealed that the highest net returns were recorded with application of mepiquat chloride@1500 ml ha ${ }^{-1}$ over other treatments in Bt cotton hybrid NCS855 BGII. 
Tuppad et al., (2017) reported that genotype RAH 274 at a spacing of $45 \mathrm{~cm} \times 15 \mathrm{~cm}$ along with application of chemical defoliator Ethrel @ 2000 ppm recorded highest gross returns, net returns and $\mathrm{B}: \mathrm{C}$ ratio over other treatments.

In a two-year study conducted at Punjab Agricultural University, Faridkoton loamy sand soils, Kulvir et al., (2015) reported that application of Dropp ultra $200 \mathrm{ml} \mathrm{ha}^{-1}$ significantly registered higher net returns (Rs. $85373 \mathrm{ha}^{-1}$ ) and $\mathrm{B}$ : $\mathrm{C}$ ratio (2.31) over other treatments. Application of defoliants at 150 DAS resulted in significantly improved net returns (Rs. $79288 \mathrm{ha}^{-1}$ ) as compared to earlier application at 140 DAS (Rs. $73632 \mathrm{ha}^{-}$ $\left.{ }^{1}\right)$.

From the above reviews, it can be concluded that, application of defoliants at optimum time enhances the defoliation percentage, boll opening percentage and yield. It also resulted in higher net returns and benefit -cost ratio without compromising the cotton crop quality. Application of defoliants leads to earliness in cotton, which provide timely sowing of next crop, by vacating the field 1015 days earlier.

\section{References}

Awan, H.U., Awan, I.U., Mansoor, M., Khakwani, A.A., Khan, M.A., Ghazanfarullah and Khattak, B. 2012. Effect of defoliantapplication at different stages of boll maturityand doses of sulfur on yield and quality ofupland cotton. Sarhad Journal of Agriculture. 28 (2): 245-247.

Buttar, G.S. and Singh, S. 2013. Effect of Ethrel dose and time of application on growth, yield and duration of Btcotton in semi arid region of Punjab. Journal of Cotton Research and Development. 27 (1): 60-62.
Collins, G.D., Edmisten, K.L., Wells, R and Whitaker, J.R. 2017. The effects of mepiquat chloride applied to cotton at early bloom and physiological cutout. The Journal of Cotton Science. 21:183189.

Fatullateshaev and Khaitov, B. 2015. Effect of defoliants and fertilizers on yield and quality of cotton. Journal of Cotton Research and Development.29 (1): 5760.

Gormus, O., Kurt, F and Sabagh, A.E. 2017. Impact of defoliation timings and leaf pubescence on yield and fiber quality of cotton.Journal of Agriculture Science and Technology.19: 903-915.

Karademir, E., Karademir, C and Basbag, S. 2007. Determination the effect of defoliation timing on cotton yield and quality.Journal of Central EuropeanAgriculture. 8(3): 357-362.

Kataria, G.K and Khanpara, M.D. 2012. Effect of cycocel and mepiquat chloride on physiology, growth and yield of irrigated Bt cotton (Gossypium hirsutum L.). International Journal of Scientific Research.1(1): 90-91.

Kulvir, S and Pankaj, R. 2015. Effect of different defoliants and their rate and time of application on American cotton cultivars under semi-arid conditions of north-western India. Research on Crops. 16 (2): 258-263.

Kulvir, S., Pankaj, R and Gumber, R.K.2015. Impact of harvest aid defoliants on yield of American cotton and their monetary evaluation. International Journal of Plant Research.28 (2): 41-46.

Meena, R.A., Monga, D and Ratna, S. 2016. Effect of defoliation on maturity behaviour and seed cotton yield in cotton. Journal of Cotton Research and Development. 30 (1): 63-35.

Mrunalini., K and Sreerekha, M. 2018. Dose dependent response of different defoliants on percent defoliation in high 
density cotton. Journal of cotton Research and Development. 32(1):116121.

Mrunalini, K., Sreerekha, M., Murthy, V.R.K and Jayalalitha, K. 2019. Impact of harvest-aid defoliants on yield and economics of high density cotton. Indian Journal of Agricultural Research. 53 (1): 116-119.

Osman, C., Demire U., Polat, R and Mehmet, A. G. 2010. Effect of different defoliants and application times on the yield and quality components of cotton in semi - arid conditions.African Journal of Biotechnology. 9(14): 20952100.

Raghavendra, T and Rama Reddy, Y. 2020. Efficacy of Defoliants on Yield and Fibre Quality of American Cotton in Semi-Arid Conditions. Indian Journal of Agricultural Research. 54: 1-4.

Rajni., Deol, J.S and Brar, A.S.2011. Effect of chemical defoliation on boll opening percentage, yield and quality parameters of $\mathrm{Bt}$ cotton. Indian Journal of Agronomy. 56 (1):74-77.

Ratnakumari., S, Mridula, G and Hema, G.2013. Effect of growth regulators and weedicides as defoliants on seed cotton yield of cotton. Journal of Cotton Research and Development. 27(1): 5659.

Showler, A. 2009. Efficiency of tank-mixing insecticide with defoliant against adult boll weevil (Coleoptera: curculionidae) populations as determined by late- season field disturbance trapping. Subtropical Plant Sciences.60: 58-65.

Singh, K., Singh, H.P., Rathore, P., Singh, K and Mishra, S.K. 2017. Manipulations of source sink relationships through mepiquat chloride for enhancing cotton productivity and monetary returns in north western India. Journal of Cotton Research and Development. 31 (1): 6268.

Tuppad, G. B., Shashidhara, G. B., Biradar, D. P., Alagundagi, S. C and Patil, S. S. 2017. Effect of chemical defoliator application on yield and economics of compact genotypes. Journal of Farm Science. 30(1): 28-36.

Veeraputhiran, $\mathrm{R}$ and Gunasekaran, $\mathrm{M}$. 2020.Effect of time of growth retardant application on growth of cotton plant under high density planting system. Journal of Cotton Research and Development. 34 (1): 67-61.

Wang, H., Gao, K., Fang, Sheng and Zhou, Z. 2018. Cotton yield and defoliation efficiency in response to $\mathrm{N}$ and harvest aids. Agronomy Journal. 110 (7): 1-8.

Wang Fang Yong., Han Huan Yong., Lin Hai., Chen Bing., Kong Xian Hui., Ning Xin Zhu., Wang Xu wen., Yu yu and Liu Jing de. 2019. Effects of planting patterns on yield, quality and defoliation in machine harvested cotton. Journal of Integrative Agriculture. 18(9) :20192028.

\section{How to cite this article:}

Sravanthi. S., M. Sree Rekha, B. Venkateswarlu, Ch. Sujani Rao and Jayalalitha. K. 2020. An overview of Defoliants Use in Cotton. Int.J.Curr.Microbiol.App.Sci. 9(07): 833-838. doi: https://doi.org/10.20546/ijcmas.2020.907.096 